\title{
Erotismo \& pornografia na arte: uma história mal contada?
}

\author{
Afonso Medeiros \\ UFPA - Universidade Federal do Pará
}

\section{Resumo}

Este artigo traça um panorama sobre as fronteiras entre erotismo e pornografia na arte e na cultura visual. Percorrendo pontualmente a representação do desejo e da sedução na história da arte, discute-se a diluição dos limites valorativos entre o erótico e o obsceno, recorrendo a autores como Gianni Vattimo, Georges Bataille, Jean Baudrillard, Poul Gerhard, Arthur Danto, Henri-Pierre Jeudy e Hans-Jürgen Döpp, dentre outros.

Palavras-chave: artes visuais; erotismo; pornografia; cultura visual.

\section{Abstract}

This article provides an overview of the boundaries between eroticism and pornography in art and visual culture. Punctually covering the representation of desire and seduction in art history and discusses the dilution of evaluative boundaries between the erotic and the obscene, approaching authors such as Gianni Vattimo, Georges Bataille, Jean Baudrillard, Poul Gerhard, Arthur Danto, Henri-Pierre Jeudy and Hans- Jurgen Dopp, among others.

Keywords: visual arts; eroticism; pornography; visual culture.

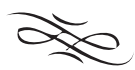

Ao longo dos oito anos (2007-2014) que me debrucei sobre a representação do desejo e da sedução na história da arte e na cultura visual ${ }^{1}$ - considerando que as fron-

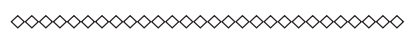

1 Este artigo, ora revisto e ampliado pelo autor, foi originalmente publicado nos Anais do $19^{\circ}$ Encontro da Associação Nacional de Pesquisadores em Artes Plásticas (ANPAP, 2010) e serviu de roteiro para a conferência sobre o mesmo tema apresentada no IV Diálogos Internacionais (UFPB/UFPE, 2015). Tanto no $19^{\circ}$ Encontro quanto no IV Diálogos, as conferências foram precedidas por um "discurso visual" que serviu de síntese iconográfico-conceitual sobre a pesquisa e que, por motivos os mais diversos, ainda não pode ser publicado. 
teiras entre estas disciplinas podem ser encaradas como esboços esgarçados pelo sistema de valores que caracterizam qualquer cultura - deparei-me mais uma vez com dois processos profundamente imbricados: a estética da produção e a estética da recepção, permeadas pelo que acostumei-me a chamar de "estética da reprodução", isto é, por um processo mais ou menos nítido de provocação e retroalimentação entre o ato da criação e o ato da fruição. Discutir erotismo e pornografia na arte, particularmente sob uma perspectiva histórica, comumente pressupõe a ênfase num desses processos, mas o fato é que um não vive sem o outro.

\title{
Preliminares
}

\begin{abstract}
"Naquele dia, no momento em que olhei para a figura, todo o meu ser estremeceu com uma alegria pagã. Meu sangue ferveu; meus rins dilataram-se como que com fúria. A parte monstruosa de mim que estava a ponto de explodir despertou com ardor sem precedente, censurando-me pela minha ignorância, palpitando indignadamente. Minhas mãos, completamente sem consciência, iniciaram um movimento que nunca tinham sido ensinadas a fazer. Senti alguma coisa secreta, radiante, subindo de dentro de mim, velozmente, rumo ao ataque. Subitamente jorrou, trazendo consigo uma embriaguez ofuscante...”.
\end{abstract}

(Mishima, s/d, pp. 32-33)

Em Confissões de uma máscara (Kamen no Kokuhaku, 1949), Yukio Mishima (1925-1970) expõe o turbilhão de sensações que a excitação e o consequente gozo experimentado diante da reprodução do São Sebastião (c.1616) de Guido Reni (1575-1642) lhe provocaram ainda na puberdade. Nessa confissão, de uma das muitas máscaras do autor, a sedução é tecida a partir de uma imagem que, a princípio, deveria suscitar a devoção e sentimentos espirituais que não dizem respeito aos prazeres da carne - ao contrário, uma cena de martírio simboliza o triunfo do espírito sobre o corpo. Mas, o corpo estava ali e com um olhar despudorado e não formatado pela moralidade cristã, Mishima amava nessa imagem o frescor da adolescência, a nudez sem sinais de nenhuma deterioração física e a ausência de quaisquer signos de sofrimento e agonia - a beleza física em seu ápice. O escritor japonês nutriu uma verdadeira fixação por essa imagem durante toda a vida, a ponto de, já adulto, afirmar que a morte deve surpreender o corpo em sua plenitude e deixar-se fotografar como o mártir dos primeiros tempos do cristianismo.

Nem precisaríamos desse testemunho de Mishima para afirmar que a imagem do corpo excita e provoca sensações e emoções únicas, fazendo "ferver o sangue", "dilatar os rins", lubrificar as entranhas, abrir os poros, eriçar os pelos, aquecer a pele e contorcer 
os membros para transbordar em espasmos, gozos, gritos e sussurros. A imagem do corpo, sempre sedutora, tem o poder de colocar o corpo do Outro em estado de alerta, de provocar o desejo e por em ação as forças incontroláveis, vivificadoras e dionisíacas da libido e da luxúria. Por isso, a imagem do corpo é cerceada, encoberta, censurada... A mais comum das iconoclastias é aquela dirigida contra a representação do corpo e de seus apetites.

A expressão e exposição da sensualidade ou da carnalidade (para sermos bem explícitos) ainda é objeto de repressão e sublimação em todos os campos, inclusive no campo da arte. Mesmo considerando-se a massiva exposição do corpo (particularmente do feminino) nas mídias e a sua proeminência na arte contemporânea, os modos de produção e veiculação das imagens luxuriosas obedecem a regras bem determinadas, liberando-se a sensualidade implícita e interditando-se a explícita - permite-se o erotismo, censura-se a pornografia. A excitação que a imagem sensual provoca ainda é considerada uma experiência exclusiva da ordem do privado e sua exposição pública é regida pela norma do "atentado ao pudor", sempre vigilante e introjetado.

A visão da sexualidade é interditada - portanto, inexprimível - desde a infância, pelo menos no Ocidente. Pedagogos e psicólogos conhecem bem os testes baseados na representação do corpo utilizados na psicologia. Quanto mais o desenho de uma criança é "realista", com detalhes como olhos, sobrancelhas, boca, nariz, orelhas, cabelos, pés, pernas, braços, mãos e dedos mais ela ganha pontos, pois isso é considerado como sinal de inteligência, percepção arguta e adaptação ao meio social que o circunda. A ausência de um ou mais desses componentes físicos, ao contrário, faz com que a criança perca pontos. No entanto, essa regra tem uma curiosa exceção. Se a criança acrescentar aos seus rabiscos os órgãos sexuais e, portanto, seu desenho for mais "realista" e detalhado, ela perde pontos, pois isso é sinal de algum distúrbio. Expressar o corpo com riqueza de detalhes é muito bom, mas se entre esses detalhes aparecer os genitais, então o discurso muda. Ou seja, desde nossas primeiras tentativas de representação do mundo e do humano a expressão do sexo está excluída sob a presunção de que ela "macula a inocência" infantil.

Questionado sobre como a filosofia auxilia a compreensão da sexualidade na época contemporânea, Gianni Vattimo, em entrevista à revista Cult, expõe o tamanho da ferida:

"Esta é uma questão muito difícil, porque não conseguimos considerar "objetivamente", pois estamos imersos na situação problemática que se deveria resolver na resposta. [...] Quem pode dizer, filósofo ou não, que tenha resolvido, de modo satisfatório, o problema da sensualidade? E, por outro lado, será verdade que não haveria ninguém que preferisse não ser atormentado por esse espinho? A filosofia talvez nos ajude a entender que a sexualidade, com todas as suas implicações, é um aspecto, talvez, antes, o aspecto essencial da nossa finitude. $\mathrm{O}$ fato de eu, como filósofo, nunca ter me preo- 
cupado a fundo com este problema (de resto, como tantos filósofos meus mestres, inclusive Martin Heidegger) é só um sinal de que eu pertenço a um mundo ainda caracterizado pela repressão." (Vattimo, 2008, pp. 14-15)

Vattimo aquiesce que as paixões carnais passam longe do interesse da Filosofia e, além dos motivos que o filósofo enumera, pode-se acrescentar que o aparente e o sensório, mola mestra das paixões, foi sempre menosprezado por vários filósofos - pelo menos por aqueles que assimilaram consciente ou inconscientemente a condenação platônica da aparência em favor da essência. E comentando seu ativismo pelos direitos dos homossexuais quando a maioria dos intelectuais silenciava sobre a questão, Vattimo conclui:

"Por isso era tão central [para os movimentos políticos de 1968] a revolução sexual; a descoberta (Marcuse!) de que a repressão sexual era um aspecto da opressão social e econômica. [...] Vale dizer que eu estou consciente de que os problemas acerca da orientação sexual estão profundamente ligados à estrutura de classes. [...] E provo certo ressentimento por ter sido obrigado a viver minha primeira experiência erótica e de namoro como um excluído; meus amigos namoravam livremente, e eu nunca estava preparado para cortejar as pessoas pelas quais demonstrava um início de amor." (Vattimo, 2008, pp. 14-15)

Essas afirmações do filósofo italiano constituem, por si só, um roteiro de indagações ainda pertinentes - e, provavelmente, mais do que nunca atuais -, sobre a representação da sensualidade e da sexualidade. Reverberando, nessas citações, O Erotismo (L'Erotisme, 1957) de Georges Bataille (1897-1962), Vattimo indica que a sexualidade é "o aspecto essencial de nossa finitude", "espinho" que a todos atormenta e questão que permanece, simbólica e fenomenologicamente, no centro da experiência e da interpretação do ser humano.

Discutindo "ser" e "coisa", "sujeito" e "objeto", Bataille aponta questões paradoxais em seu clássico estudo sobre o erotismo:

"A animalidade subsistente do homem, sua exuberância sexual, só poderia ser considerada como coisa se tivéssemos o poder de negá-la, de existir como se ela não existisse. Efetivamente nós a negamos, mas em vão. A sexualidade, qualificada como imunda, como bestial, é mesmo aquilo que se opõe ao máximo à redução do homem à coisa." (Bataille, 2004, p. 246) 
As tentativas intrínsecas e extrínsecas de negação da sexualidade estão, sob o ponto de vista de Bataille e de Vattimo, destinadas ao fracasso, pois a "exuberância", a diversidade e a complexidade da sensualidade humana é justamente o que nos caracteriza como humanos. Em outras palavras, a negação da sexualidade é a negação do ser mais essencial da humanidade.

Pode-se mesmo afirmar que na longa história da expressão sexual, não só a filosofia, mas também a arte e todos os campos do conhecimento deram suas contribuições para a censura, a negação e a repressão do corpo, da sensualidade e da sexualidade, calcadas na pretensão de que o espírito subsiste ao corpo. Precisamente por esse motivo, vicejaram ao longo da história intelectual do Ocidente certos tipos de ideias metafísicas e religiosas que nada mais são do que tentativas de desqualificação da imanência, da carnalidade, da corporeidade humana.

O corpo e a manifestação da sexualidade, por si sós, desautorizam aquela dicotomia fajuta entre natureza e cultura. Um corpo é, em si mesmo, natureza e cultura, sujeito $e$ objeto de todas as percepções, sensações e intelecções que certa tradição do pensamento pretendeu hierarquizar e definir em esquemas teóricos opositivos. O corpo não é um suporte para a infinitude ou um passaporte para a transcendência; não é um "aquém" da essência... Ele é a própria essência do ser humano. Tudo o que um corpo percebe, sente, pensa e expressa são manifestações do nosso modo de ser e estar no mundo.

Nietzsche dizia que "O corpo [é] advogado da imanência, refutação palpável da mentira metafísica” (apud Paolo Fabbri, 2004, p. 3). A essencialidade do carnal e do animal descontrola todos os mecanismos de disciplinamento e domesticação do humano. Causa medo e fascínio, horrores e deleites, paixões e maldições.

Ritualizado, sacrificado, esmagado, escarnecido, glorificado, estilizado ou estetizado, o corpo é o índice por excelência do humano. A corporeidade é o rastro de nossa presença no mundo, suporte de todos os êxtases e de todas as agonias que configuram a humanidade. Ao mesmo tempo signo e objeto, o corpo ainda é confundido com sua própria exterioridade em oposição à sua suposta interioridade (a alma ou espírito) que nele habitaria ou dele se nutriria momentaneamente. O corpo finito e o espírito supostamente infinito digladiam-se incessantemente no campo de batalha do estatuto do humano.

O corpo nunca foi uma questão periférica para a arte em particular e para a cultura visual em geral. A produção de imagens do corpo e da sexualidade é tão extensa e multifacetada que o ato de interpretá-las é um procedimento de alto risco. Apesar dessa presença monumental do corpo na história das imagens, as teorias da arte, grosso modo, ainda não responderam satisfatoriamente ao problema da manifestação do desejo e da sedução, talvez porque não tenhamos nesse campo, por motivos que só a censura explicaria, uma história da representação do corpo e da sensualidade - a bibliografia estranhamente escassa sobre o assunto é só uma prova disso. Nunca é demais afirmar que, de todos os tipos de discursos relativos à sensualidade e à sexualidade, o visual é 
certamente o mais censurado e, no campo da arte, subsiste uma estranha desqualificação do que é caracterizado como pornografia. No entanto, como diz Bataille, a negação é vã e inútil pelo simples fato de que as imagens de conteúdo erótico continuam a assombrar, a desestabilizar mentalidades e a oferecer prazeres, mesmo que "sujos" e inconfessáveis.

Das pinturas parietais à arte digital, a imagem do corpo parece exercer um fascínio que não dá sinais de esgotamento e tem atravessado culturas, estilos, escolas, tendências e movimentos variados nos tempos e nos espaços. A sobrevivência desse fascínio é ainda mais contundente quando lembramos que o corpo e sua representação, muitas vezes, foram negados não só pelas religiões monoteístas, mas também pela filosofia ocidental - que, a rigor, jamais se preocupou com a "carnalidade" do corpo, embora o tenha considerado sob diversos aspectos (cf. Cardim, 2009).

Em muitas culturas, particularmente nas panteístas, não havia uma interdição à nudez corporal e, até mesmo, ao que hoje caracterizar-se-ia como imagem pornográfica - os murais de Pompéia, a cerâmica grega e a escultura indiana são exemplos bem conhecidos. Por outro lado, não foram poucas as culturas que encobriram o corpo com uma burca ou um hábito. Na cultura ocidental de influência européia, essa interdição instala-se com a ascensão das religiões monoteístas. Rituais que tinham o corpo como suporte foram caracterizados como "possessão demoníaca" ou como "paganismo" e "barbárie". A confluência entre monoteísmos, platonismos e budismos construiu, ao longo dos séculos, um fosso profundo entre alma e corpo, entre transcendência e imanência, de modo que o corpo e a sexualidade fossem negados, distorcidos, condenados e perseguidos.

Quando as burcas e hábitos eram a regra e não a exceção, a imagem do corpo nu persistiu, mesmo que travestido na pele do mito, do herói ou do santo, e não raramente causou escândalos (Donatello, Michelangelo, Tiziano, Caravaggio, David etc.). Aliás, o recurso ao mito, ao herói e ao santo foi uma forma de driblar a interdição ao nu e expor o corpo, mesmo que de maneira muitas vezes idealizada e contribuindo diretamente para a sublimação do corpóreo e da sexualidade. Com Goya, Coubert, Manet e Schiele (dentre outros), abandona-se paulatinamente a idealização e se instaura uma representação do corpo mais humana e erotizada - mais carnal, pode-se dizer. Por outro lado, ao longo desse trajeto que vai do Renascimento ao início do século 20, muitos artistas produziram obras de caráter claramente obsceno, mas essa produção foi convenientemente relegada às bordas da história e "esquecida" pelos historiadores da arte até recentemente. Ou seja, ficou na sombra, na penumbra... Literalmente, assunto de alcova.

Conforme as histórias canônicas da arte, a representação do humano explicita-se no trabalho, na política, na religião, na mitologia, na história, na ciência e na natureza, mas não se encontra uma só imagem que explicite o exercício da sexualidade humana. A crer exclusivamente nesse discurso e nesse imaginário privilegiado pela história da arte, o ser humano não deseja o outro, não provoca a sedução, não fornica, não faz sexo, não goza... Enfim, não tem emoção sensual, não experimenta os apetites da paixão em seu próprio corpo. 
Com o advento da fotografia, a representação do nu ainda travestiu-se de "artístico", de "científico" ou de "mitológico", mas logo se escancararam todos os pudores em relação ao corpo e, desde então, a história da sensualidade na arte - e, por extensão, do desejo e da sedução - tornou-se mais que pura tendência ou gênero artístico a ponto de, desde a última década do século 20, multiplicarem-se as mostras com esse tema convenientemente "esquecido" por séculos.

Os modernismos da primeira metade do século 20 promoveram a deformação e a fragmentação do corpo, enquanto sua segunda metade, a par da pretensa liberação de todas as formas de repressão, sobretudo as sexuais instaladas no epicentro de Maio de 68, viu o corpo sensual e sexualizado assumir a cena em happenings, performances e mais uma diversidade de experimentações, não sem as devidas polêmicas. É o momento da bacanal da modernidade, conforme definição de Jean Baudrillard:

\begin{abstract}
"A orgia é o momento explosivo da modernidade, o da liberação em todos os domínios. Liberação política, liberação sexual, liberação das forças produtivas, liberação das forças destrutivas, liberação da mulher, da criança, das pulsações inconscientes, liberação da arte. Assunção de todos os modelos de representação e de todos os modelos de anti-representação". (Baudrillard, 1990, p. 9)
\end{abstract}

O erotismo tornou-se tema de concorridas exposições, provocou debates calorosos em congressos e similares em todo o mundo e, enfim, musealizou-se. Aliás, a existência de museus dedicados exclusivamente a obras "eróticas" (em Paris e Las Vegas, por exemplo) reitera a ocultação do tema não só nas exposições permanentes dos museus de arte, mas na própria história da arte - a liberação apontada por Baudrillard na modernidade, com raríssimas exceções, não se verificou nos discursos sobre o corpo na área de arte, conforme pretendo demonstrar neste ensaio.

Os escândalos causados pela exposição do David de Michelangelo, da Vênus de Urbino de Tiziano, da Maja Desnuda de Goya e da Olympia de Manet - dentre muitos outros exemplos - podem parecer coisas do passado, pruridos de moralismos já superados. Entretanto, a exposição no metrô de um cartaz de divulgação da mostra consagrada a Lucas Cranach (1472-1753) na Academia Real de Londres que reproduzia uma vênus (1532) do mestre renascentista, causou uma estonteante polêmica, com a alegação de insulto à moral e ofensa à religião - isso em fevereiro de 2008! Se a reprodução de uma vênus que já tem veneráveis 484 anos é considerada obscena quando exposta em local público, torna-se imperativo aquiescer que a expressão da sensualidade ainda é um tema espinhoso em pleno século 21. A questão, portanto, parece não residir somente na expressão em si, mas no local onde ela é apresentada. As querelas conceituais entre "erótico" e "pornográfico" passam não só pelo modo expositivo (público ou privado), mas também pela diferenciação valorativa da reprodutibilidade. 
Imagens consideradas pornográficas manifestaram-se particularmente nas técnicas da reprodutibilidade (gravura, fotografia e vídeo - cf. Medeiros, 2008) e em consonância com essa trajetória a representação da sexualidade encontrou nas mídias digitais seu mais perfeito veículo, próprio para o deleite privado, anônimo e despessoalizado. Discutindo o corpo na perspectiva que se apresenta desde a modernidade, Le Breton (2003) observa a passagem do "corpo rascunho" ao "corpo acessório" na contemporaneidade, rearranjado e reparado até tornar-se mero suporte da pessoa e não algo intrínseco a ela. E vale dizer que isso não é perpetrado somente pelo biopoder da ciência e da tecnociência (como aponta Le Breton), mas também pelo alcance dos modelos estéticos sobre o corpo e a sexualidade que a arte construiu e, convenhamos, continua construindo.

$\mathrm{Na}$ verdade, o corpo e a sexualidade vêm sendo despessoalizados há séculos e a arte, quando idealiza ambos, está profundamente imbricada nessa questão. Um texto de apresentação num site de fotografias e desenhos pornoeróticos (galleries.adult-empire. com) reitera essa percepção:

"[...] Só aqui você tem a oportunidade de satisfazer a todas as suas sujas fantasias. É melhor do que homens de verdade, porque aqui você vai encontrar só os caras mais bonitos do mundo [...] e sexo selvagem! [...]".

$\mathrm{Na}$ abordagem do corpo e da sexualidade, a arte também provoca e seduz, tal como expresso na citação anterior, ou seja, idealiza o corpo e seus sabores, atiçando a fantasia e a imaginação, criando simulacros e uma verdadeira mitologia em torno do corpo. O que me espanta é que raros historiadores da arte explicitem essa questão com a profundidade que ela merece.

Nessa perspectiva aqui exposta sucintamente, uma história do pornoerotismo na arte deve assumir o confronto com os próprios cânones da história da arte.

\section{Arte x erotismo x pornografia}

A despeito da onipresença da representação do corpo na arte, a discussão sobre a manifestação - implícita ou explicita - do desejo e da sedução não acompanha essa proeminência. Se o erotismo tem sido um tema/discussão mais ou menos recorrente na arte, o mesmo não acontece com a pornografia - tanto em abordagens históricas quanto filosóficas, sociológicas, psicológicas ou educacionais aplicadas à arte. A simples menção da palavra "pornografia" acarreta estranhamento e, no campo das artes visuais, resume-se tudo ao termo "erotismo" (cf. Medeiros, 2008). No tratamento do tema persiste a ideia de que basta uma inversão de sentido dos signos (entre pornografia e erotismo) 
para se resolver a questão. E, no entanto, a pornografia é, ao mesmo tempo, ascendência e descendência do erotismo na medida em que a existência de ambos é inextricável e essencialmente interdependente. Em outros termos, não existe erotismo sem pornografia e vice-versa.

Trocando em miúdos: a crer nas definições sobre a representação do corpo e da sexualidade que muitos estudiosos construíram a partir da produção artística, o pornografismo simplesmente não existe para a quase totalidade dos historiadores, filósofos, sociólogos, educadores e críticos de arte. Poul Gerhard expõe uma dessas tensões entre os conceitos de erotismo e pornografia na arte:

\begin{abstract}
"Em 1968, a Suécia realizou a sua primeira exposição de arte pornográfica. Mas, infelizmente, os organizadores não conseguiram reconhecer a palavra pornografia. Em vez disso, eles descreveram a exposição como uma mostra de arte erótica e propuseram uma tentativa de distinguir esta última da pornografia, ao tratar pornografia como especulação financeira prejudicial, e arte erótica como uma forma de arte meritória. Esta distinção apenas preservou uma confusão de ideias claramente demonstrada na legislação, a qual, por um lado, permite arte de conteúdo erótico, enquanto, por outro, pró́be pornografia. Uma indicação da impraticabilidade de tal distinção é o caos jurídico que ocorre com tanta freqüência nos últimos anos, quando a questão da pornografia tem sido levada aos tribunais. [...] Os limites da arte pornográfica são mais do que formalmente fixos, e surge o fato de que a atividade artística-pornográfica não está restrita a um período particular, nem está ligada a nenhum 'ismo'. Arte pornográfica é tão antiga quanto a própria arte”.
\end{abstract}

(Gerhard, 1971, p. 9)

Assim, Gerhard reitera o que qualquer estudioso mais atento pode perceber acerca dessa questão. Existe uma clara resistência quanto ao uso da palavra "pornografia" na área de arte, o que faz do "erótico" um conceito tão amplo, ambíguo e líquido que quase o torna um "signo vazio" (no sentido de Barthes). Outra questão, também apontada por Gerhard é o fato de que a arte pornográfica não se restringe a um "ismo", período ou estilo e essa transversalidade do corpo e da sexualidade na arte, para historiadores acostumados com uma história linear, de sucessão de estilos, épocas e movimentos, é problemática nos termos de uma abordagem estritamente diacrônica. Eis, aqui, dois bons motivos para se revisar a história da arte sob o ponto de vista da visualidade pornoerótica.

O fato é que a representação da nudez ainda causa escândalos, principalmente quando é um signo explícito da sexualidade e a questão é, certamente, delicada, pois provoca paixões intensas e a manifestação de preconceitos há muito arraigados - há quem negue a confluência entre arte e erotismo ou tente retirar da representação do 
corpo qualquer referência erótica.

Jacques Derrida (1930-2004) e vários pensadores contemporâneos já discutiram como o pensamento ocidental erigiu "leis" duais e opositivas em nome de uma suposta homogeneidade da lógica científica. Essas "leis" claramente acarretam a exclusão de algumas das mais importantes características do pensamento e, consequentemente, do conhecimento, qual sejam, a complexidade, a mediação e a diferença. Aplicadas ao campo da arte e, mais especificamente, às histórias da arte, erotismo e pornografismo são modos de representação supostamente irreconciliáveis e observa-se nitidamente uma preferência daquele em detrimento deste, evitando-se assim, justamente, a complexidade, a mediação e a diferença. Ainda de acordo com Derrida, o dualismo de caráter opositivo contém paradoxos que são insuficientes para desvelar a complexidade dos processos de pensamento e embora seja praticamente impossível desconsiderar essa herança dual, o processo de desconstrução desse discurso serve para o necessário exercício da invenção e da criatividade. No caso específico das imagens sensuais a questão torna-se ainda mais complexa na medida em que o corpo cria seu próprio discurso, irredutível à simples oposição conceitual entre erótico e pornográfico. Por esse motivo, parece-me premente uma revisão dos dualismos e oposições expressos na interpretação que a história da arte faz da sexualidade não só para explicitar esse jogo maniqueísta e redutor, mas para incitar a revelação da complexidade, da mediação e da diferença intrínsecas ao tema. Um exemplo clássico é a misoginia que perpassou várias das chamadas "vanguardas históricas" europeias e que, até recentemente, muito raramente aparecia nos discursos de historiadores, críticos, curadores e professores de arte.

Diante desse cenário e do evidente pudor que o tema suscita, resta-me a provocação: quem nunca experimentou deleites nas imagens pornográficas, que atire a primeira pedra! Desde já, devo esclarecer que se trata de investigar a imagem literalmente excitante, aquela que provoca a libido do expectador.

Investigar as formas de representação do desejo e da sedução, explicitando o pornografismo também como expressão e valor a serem considerados, parece causar constrangimento, principalmente através de um silêncio obsequioso. Desconfio que enfrentar a expressão do desejo e da sedução em todas as suas manifestações sem um entrave moralista é comumente percebido como uma questão que deve ser confinada aos "estudos de gênero", como uma espécie de diletantismo alheio à história da arte enquanto campo de conhecimento.

A crer nas conclusões temporárias que tenho retirado do percurso investigativo, as fronteiras entre erotismo e pornografia são "líquidas", tênues, rarefeitas... Por essa razão, assumo neste ensaio o termo "pornoerotismo" para deixar claro que para além do dualismo opositivo verificáveis nas operacionalizações dos termos "erótico" e "pornográfico", devem-se perceber as mediações, as trocas, as confluências e as cópulas do pensamento que constrói o conhecimento sobre o corpo e a sensualidade - e o termo "conhecimento" aqui se refere não só ao discurso verbal, mas também e, sobretudo, ao discurso visual ou, melhor dizendo, à construção do discurso verbal a partir do visual. 
"Por debaixo dos panos", há a pretensão de se proceder a uma revisão dos cânones estabelecidos pela história da arte a partir da expressão do corpo e da sexualidade, mesmo que a natureza de um texto como este não nos permita ir muito longe.

Alguém poderia conjecturar que seria menos pretensioso uma "história do pornoerotismo na arte", mas isso me obrigaria a uma abordagem de um assunto (o pornoerotismo) dentro de uma história (a da arte) cujas fronteiras já estão dadas e que, todos sabem, está eivada de preconceitos e etnocentrismos, me impedindo de experimentar enquadramentos e deslocamentos diversos. Por outro lado, considerando-se que a história da arte é uma ciência da interpretação dos fenômenos ditos artísticos ou, melhor dizendo, uma história de juízos de gosto e de valor, ela é sempre passível de revisão e novos enquadramentos - como, aliás, Hans Belting e Arthur Danto vêm defendendo pelo menos desde os anos 80 do século passado. Em síntese, a percepção dessa história "mal contada" obriga não só a uma revisão da trajetória das representações do corpo e da sexualidade na arte, mas impõe também, a partir dessa questão, um questionamento dos pressupostos da disciplina ou, pelo menos, de alguns deles.

\section{A história mal contada}

Se admitirmos, com Giulio Argan (1994, p. 14), que "a história da arte não é tanto um história de coisas como uma história de juízos de valor" e que, com Lionello Venturi (2007), a "obra de arte" depende do gosto do artista ou de um grupo de artistas, teremos que considerar que valor e gosto são inextricáveis - como, aliás, Venturi concebia as relações entre história e crítica de arte. Assim, deduzimos que a história da arte é, basicamente, uma história de juízos de valor e de juízos de gosto, encarnados em determinado tipo de produção cultural (de dado indivíduo e/ou de dada coletividade). O valor de obra de arte foi atribuído e aplicado, inclusive retrospectivamente, a produtos e processos de povos e culturas que certamente não tinham essa intenção, ou seja, a atribuição do valor artístico da obra é arbitrária na medida em que não basta, para essa atribuição, a intenção do produtor da obra. Essa constatação reforça as percepções de Argan e Venturi sobre valores e gostos embutidos no conceito de obra de arte. Se essa premissa não estiver equivocada, teremos que admitir que a história e a crítica de arte se configuram como um espaço onde conceitos e preconceitos se cruzam incessantemente provocando vários níveis de complexidade e mediação entre o "artístico" e o "não-artístico" e que, portanto, o objeto dessas disciplinas não é necessariamente a ontologia da "obra de arte", mas os fluxos e refluxos dos valores e dos gostos permeados por conceitos e preconceitos relativos às concepções de arte. Meyer Schapiro, sempre entrelaçando história e crítica de arte, é outro autor que reitera a impossibilidade de isolamento dessas disciplinas em relação ao processo histórico. Talvez, mais do que qualquer outro pressuposto, esta é a base sobre a qual a história e a crítica da arte pornoerótica tem que ser erigida. 
Dentro desse arcabouço, um dos conceitos que permeiam a história da representação do desejo e da sedução na arte é, certamente, a dicotomia entre erotismo e pornografia. A pornografia é comumente caracterizada como representação explícita da sexualidade, exposição nua e crua, carnalidade sem amor, física, vulgar, grotesca, suja. O erotismo, por contraste, é abordado como representação velada da sexualidade, amor sem carnalidade, metáfora, metafísica, transcendental, sublime. Essa distinção não está expressa somente em termos conceituais: as fronteiras entre erotismo e pornografia na arte são claramente perceptíveis na escolha das imagens que permeiam todas as histórias canônicas da arte e até mesmo em muitos daqueles ensaios que têm o termo "erotismo" em seu título - pelo menos nas abordagens até o século 19, a única exceção é $A$ origem do mundo (1866) de Gustave Coubert. Assim percebida, essa dicotomia aponta não só para a gangorra de valores e gostos perceptível ao longo da história da arte e da crítica, mas tem profundas implicações filosóficas e estéticas. Nas últimas décadas, o termo "erotismo" tornou-se tão elástico no campo da arte a ponto de abarcar a produção claramente pornográfica de muitos artistas de anteontem, de ontem e de hoje. Não se trata de reiterar, pura e simplesmente, essa dicotomia. O que estou querendo dizer, primeiramente, é que há uma interdição (ou resistência), mesmo que velada, quanto ao uso do termo "pornografia" entre historiadores, críticos, sociólogos, antropólogos, educadores e psicólogos da arte. Essa resistência aparece também na fala de muitos artistas.

O vídeo, o cinema, as artes gráficas, as histórias em quadrinhos, a gravura e a fotografia têm um tipo de produção claramente caracterizada como pornográfica, ou "para adultos" (sua metáfora). Por que essa caracterização, com raríssimas exceções, também não recai sobre a pintura ou a escultura? Porque, em grande medida, a pintura e a escultura ainda veiculam valores e gostos canônicos na história da arte, além de continuarem sendo, a despeito dos procedimentos da arte contemporânea, as protagonistas dessa mesma história, as que oferecem o enquadramento para todas as outras artes visuais. Caracterizar como pornografia significa automaticamente um veto ao suposto status de transcendência da obra de arte? Hans-Jürgen Döpp, na introdução de 1000 obras eróticas dos gênios, expõe a dimensão do problema:

"Arte e pornografia, sexualidade e sensualidade, obscenidade e moralidade estão todos envolvidos de tal forma que é quase impossível chegar a uma definição objetiva, o que não é incomum na história da arte. [...] Uma coisa é certa: a representação de uma atividade sexual por si só não suscita uma obra com a grandeza que é a arte erótica. Identificar a arte erótica só com o seu conteúdo seria reduzi-la a uma dimensão, assim como não é possível distinguir as representações artísticas das pornográficas apenas descrevendo o seu conteúdo imoral." (Döpp, 2008, p. 7)

Com o título de "Arte erótica ou pornografia?", o texto de Döpp discute a dificuldade de definição nesse campo e reitera que o simples fato de expor a sexualidade não é suficiente para julgar o que é moral (e estético) ou imoral (e obsceno) na arte, mas ainda 
usa o termo "erotismo" de maneira ambígua, como uma categoria geral que abarca todos os tipos de manifestações da sensualidade e, assim, também evita a identificação da arte com a pornografia. Pelo exposto nesta e em outras citações, a identificação do estético com o obsceno é prejudicada pelo discurso da moralidade e seus tentáculos disciplinadores.

Em "Jogando com os limites - a realização fotográfica de Robert Mapplethorpe" (1992), Arthur Danto também tangencia a polêmica ao afirmar:

\begin{abstract}
"O conteúdo do trabalho [de Mapplethorpe] muitas vezes é suficientemente erótico para ser considerado pornográfico, mesmo pelo artista, enquanto a estética de sua apresentação é castamente clássica - é apolíneo e dionisíaco ao mesmo tempo. O conteúdo não pode ter sido uma séria possibilidade para um grande artista, em qualquer momento anterior na história; isto é peculiar à América dos anos 1970, uma década que Mapplethorpe exemplifica nos termos de seus [próprios] valores, sua sensibilidade e suas atitudes." (Danto, 1992, p. 311)
\end{abstract}

Aquela década hedonista, pós-maio de 68 e pós-stonewall que Danto afirma ver exemplificada nos valores, na sensibilidade e nas atitudes do fotógrafo estadunidense necessariamente reflete-se em sua obra. Entretanto, ao afirmar que o trabalho de Mapplethorpe é "suficientemente erótico para ser considerado pornográfico", Danto propõe uma hierarquia entre esses conceitos (a pornografia como radicalização do erotismo) e deixa entrever, nas entrelinhas, que a arte não lida com a pornografia, pelo menos não até aquele momento. Trocando em miúdos, essa citação do aclamado filósofo, historiador e crítico estadunidense é uma reiteração exemplar daquilo que venho discutindo, pois, para Danto: 1) o erótico supera o pornográfico; 2) essa superação se dá na medida em que a apresentação da obra é percebida como estética clássica; 3) a obra de Mapplethorpe é, ao mesmo tempo, dionisíaca $e$ apolínea (o grifo é do próprio Danto). Mesmo ecoando as lições de Schelling e Nietzsche de que o dionisíaco e o apolíneo se entrelaçam na manifestação poética, Danto também sugere que erotismo e pornografia são coisas distintas.

Espero ter deixado claro que entre o erotismo e a pornografia há uma escala de valores e, respondendo à pergunta que fiz alguns parágrafos acima, sim, atribui-se um valor "erótico" à representação do corpo na arte que o faz transcender a pornografia. Mesmo contextualizando a afirmação de Danto - num momento em que exposições das fotografias de Mapplethorpe causavam excitantes debates sobre o suposto caráter obsceno e pornográfico de sua obra, causando cancelamento de apoios e de mostras programadas, retirada das imagens mais picantes de algumas exposições, processos judiciais e até leis que impedissem o apoio estatal a mostras com obras consideradas imorais, pelo Senado 
norte-americano -, e percebendo uma defesa da obra do fotógrafo norte-americano ao se deslocar a discussão do pornográfico para o erótico, não há como esconder que existe certo constrangimento quanto à defesa do uso do termo "pornografia" no campo da arte e, por isso mesmo, "erotismo" tornou-se o jargão oficial de historiadores e críticos. Ou, então, teremos que considerar que a atribuição do valor "erótico" a uma obra é - nada mais, nada menos - uma tentativa de eliminar o "espinho" da sensualidade nos discursos de e sobre a arte.

As polêmicas causadas pelas exposições de Mapplethorpe nos anos 90 do século passado são marcos na querela entre erotismo e pornografia. Até então, o que se via geralmente era a exposição velada da sexualidade, com raras e pontuais exceções. Com Mapplethorpe, expõem-se membros eretos, cenas de sadomasoquismo, sexualidade escancarada, à flor da pele e as discussões extrapolam em muito as fronteiras do mundo da arte... Desde a Pop Arte e a Arte Conceitual dos anos 60 do século passado a arte subitamente perde o pudor: Andy Warhol, Shigeko Kubota, Nan Goldin, Nobuyoshi Araki, Márcia X, Yuri Firmeza, John Currin, Takashi Murakami... retrospectivas, publicações, revisões e reavaliações veem a tona: Rembrandt, Rubens, Hokusai, Courbet, Schiele, Picasso, Dali, Klimt, Alair Gomes e mais uma infinidade de artistas finados têm suas obras pornoeróticas finalmente expostas para um público mais amplo. Cicciolina (via Jeff Koons) torna-se a nova madona das bienais e as relações entre arte e pornografia entram no horizonte da crítica e da história da arte, mesmo que, como vimos, quase nunca percebida de maneira despudorada. Os artistas rasgaram os véus, mas muitos críticos e historiadores não souberam (ou não quiseram) traduzir essa avalanche luxuriosa.

A questão dos valores atribuídos ao que é erótico em contraposição ao que é pornográfico provavelmente também envolve uma clara delimitação de mercados e circuitos. Se um produto (filme, pintura, fotografia etc.) erótico-pornográfico for produzido no circuito/mercado da arte, ele será considerado obra de arte. Se o produto, desde sua gênese, for produzido no circuito/mercado "pornô", dificilmente ele atingirá o status de obra de arte... Ou seja, as características (potencialidades) estéticas do pornografismo são rechaçadas a priori. Uma das críticas mais batidas e hipócritas sobre a pornografia é a de que ela é uma indústria (do entretenimento) que move bilhões de dólares, como se o "sistema da arte" (eufemismo para uma verdadeira indústria) também não movimentasse bilhões de dólares.

Nessa delimitação de valores, sub-repticiamente também se instala um "bom gosto" pró-erotismo e um "mau gosto" pró-pornografia. A despeito das apropriações ou referências que muitos artistas contemporâneos fazem em relação à indústria pornográfica, essas relações raramente são problematizadas ou explicitadas. O fato é que fotos e esculturas da Cicciolina fornicando com Koons é "arte erótica” exposta até na mais prestigiada das bienais. Já os vídeos e fotografias da ex-deputada italiana com artistas pornôs são "pornografia", pura e simplesmente - ou seja, a questão também parece residir no tipo de artista com quem Cicciolina se deita.

O que Koons, Currin, Araki, Bacon, Mapplethorpe e Murakami (dentre muitos 
outros) fazem ou fizeram em algum momento de suas carreiras é pornografismo - ou "alta pornografia" como prefere Calvin Tomkins (2009) referindo-se a Koons, reiterando mais uma hierarquia entre o "alto" e o "baixo" dos prazeres corpóreos que Mikhail Bakhtin (1993) já havia assinalado. É representação explícita da sexualidade humana, mesmo que embrulhadas por uma estética clássica/erótica/apolínea como dizia Danto. Não é meramente erotismo, pelo menos não no sentido comum do termo. Ou será que a imagem pornográfica, ao assumir o valor de obra de arte através da apropriação produzida pelo artista, recebe automaticamente o carimbo "transcendental" de erotismo, o que a distancia da "sujeira" do pornografismo? Pelo que percebemos até aqui, parece que sim. Eis mais um exemplo de como a história é mal contada quando se trata de imagens obscenas na arte:

\footnotetext{
"Courbet siguió reanudando con el desnudo femenino, a veces con una inspiración obviamente libertina. Pero con El Origen del mundo, se autoriza un atrevimiento y una franqueza que proporcionan al cuadro su poder de fascinación. La descripción casi anatómica de un sexo femenino no está matizada por ninguna artimaña histórica o literaria. Gracias a la gran virtuosidad de Courbet, al refinamiento de una gama de colores ambarina, El Origen del mundo se salva no obstante del estatuto de imagen pornográfica. La franqueza y el atrevimiento de este nuevo lenguaje no excluyen un vínculo con la tradición: de modo que la pincelada amplia y sensual, junto con la utilización del color, recuerda la pintura veneciana y, el mismo Courbet se reclamaba del Ticiano, de Veronese, de Corregio, y de la tradición de una pintura carnal y lírica". (Texto de apresentação da obra A Origem do mundo de Gustave Courbet no site do Museu D’Orsay - grifos meus).
}

Enquanto constata-se que Courbet não apelou para artimanhas históricas ou literárias - e eu acrescentaria, mitológicas - para velar o desejo e a sedução puramente carnais, se evoca a maestria do pintor para "salvar" A Origem do mundo do rol das imagens pornográficas. O que isso significa? Que as imagens obscenas, se bafejadas pelo apuro técnico-artístico, salvam-se da vala comum da pornografia? Basta uma "grife artística" para transformar o valor e o significado de uma obra?

Se, como vimos muito rapidamente, o pornografismo atravessa tanto o campo da arte como o campo mais vasto da cultura visual, porque, então, a produção da indústria pornográfica tem sido negligenciada por historiadores e críticos de arte? Tendo influenciado tantos artistas, por que a imagem pornográfica não é discutida, pelo menos como referência e apropriação ou, pelo menos, como propiciadora de experiência estética? E tem mais: Por que a produção com características pornoeróticas de tantos períodos e artistas - Giulio Romano, Rembrandt e Picasso, para ficarmos em poucos e conhecidís- 
simos exemplos do passado - não são expostas nas histórias canônicas da arte? Uma resposta plausível é o fato de que apenas o mítico, o religioso e o heróico foram, por muito tempo, considerados como temas dignos da "grande arte". Com o século 19, o mundo da arte passou a admitir também cenas da vida cotidiana, paisagens e naturezas mortas como temas que, além da demonstração de excelência técnica, propiciavam a veiculação da emoção do artista e, por isso, dignos da atenção do historiador e do crítico. Mas por que o sensual $e$ o sexual foram esquecidos? Tudo isso não nos interpela, não nos exige um olhar mais demorado e atento?

Não faz muito tempo, as obras consideradas pornográficas de muitos artistas estiveram escondidas nos escaninhos de museus e coleções particulares e, assim, constituíam um verdadeiro submundo da arte ou, no máximo, uma "Galeria de Obscenidades" (a exemplo da estabelecida em Nápoles em 1819), com acesso restrito aos "adultos de moral ilibada”. Não nos foi dito que muitos artistas famosos, além de heróis, mitos, santos, paisagens e naturezas mortas também plasmaram o humano em plena atividade sexual... Deve-se reiterar que boa parte dessa produção pornoerótica teve o papel como suporte, material que, além de ser considerado menos nobre do que aqueles utilizados pela pintura e pela escultura é perfeito para o silêncio dos arquivos.

Essa invisibilidade do conteúdo pornoerótico da arte - há muito existente, mas comumente velado - é um dos pilares das teorias transcendentais da arte, da sublimação do corpo na "grande arte" e da tardia assunção do cotidiano como tema "nobre" na história e na crítica de arte. Eis outro motivo para se desconstruir os discursos pudicos e edulcorados de tantos historiadores e críticos de arte.

Entre a sublimação do corpo na arte e a massiva exposição do corpo na cultura visual, Henri-Pierre Jeudy reitera a percepção que expressei anteriormente:

\footnotetext{
"Comparar o corpo a um objeto de arte seria uma maneira, ao menos usual, de dessexualizá-lo. Colocado sobre um pedestal, o corpo está ali para ser admirado, e não tocado; torna-se inacessível, já que em geral não se apalpa uma obra de arte. [...] A admiração é o meio moral e estético de sublimar o desejo. [...] Se considerarmos, ao contrário, que a multiplicidade e a irrupção das imagens corporais alteram os critérios da representação e sua hierarquia convencional, uma tal concepção de sublimação não resiste. É o desejo que se acha confrontado com o poder inalterável de sua própria soberania. As imagens corporais não respeitam o princípio da sublimação; acontecem sem se submeter a nenhuma regra estética." (Jeudy, 2002, pp. 23-24)
}

Para as pretensões deste ensaio, é importante sublinhar duas das afirmações de Jeudy: "a multiplicidade e a irrupção das imagens corporais alteram os critérios da representação e sua hierarquia convencional" e "as imagens corporais não respeitam o 
princípio da sublimação; acontecem sem se submeter a nenhuma regra estética”. Ou seja, a imagem do corpo e a expressão da sexualidade não podem estar subordinadas ao princípio da sublimação, da admiração pura e simples; ela estabelece suas próprias regras; regras que não dizem respeito à transcendência de qualquer natureza, mas, ao contrário, dizem respeito à imanência do corpóreo. Mario Vargas Llosa, com outras palavras, corrobora esse entendimento:

"O erotismo tem a sua própria justificação moral, porque significa que o prazer é suficiente para mim; é uma afirmação da supremacia do indivíduo" (Vargas Llosa, apud Joaquim Afonso in Desenhos eróticos, 2006).

Pelo exposto por Jeudy e Vargas Llosa, para que a imagem pornoerótica literalmente "saísse do armário", seria necessária uma ampla revisão desses padrões estéticos e morais que perpassam não só a história, mas também boa parte da crítica e da teoria da arte em geral, já que, como bem assinala Jeudy, "A admiração é o meio moral e estético de sublimar o desejo". As afirmações de Vargas Llosa, Jeudy, Bataille e Vattimo, reverberando Nietzsche - "O corpo [é] advogado da imanência, refutação palpável da mentira metafísica" - e reivindicando a soberania do corpóreo e do imanente, apontam para a possibilidade de, no campo da arte, evitar os juízos de valor moral e, para além disso, instituir o debate no campo da ética, nos termos em que Terezinha Rios expressa:

"A ética se apresenta como uma reflexão crítica sobre a moralidade, sobre a dimensão moral do comportamento do homem. Cabe a ela, enquanto investigação que se dá no interior da filosofia, procurar ver - como afirmei antes - claro, fundo e largo os valores, problematizá-los, buscar sua consistência. É nesse sentido que ela não se confunde com a moral. No terreno desta última, os critérios utilizados para conduzir a ação são os mesmo que se usam para os juízos sobre a ação, e estão sempre indiscutivelmente ligados a interesses específicos de cada organização social. No plano da ética, estamos numa perspectiva de um juízo crítico, próprio da filosofia, que quer compreender, quer buscar o sentido da ação." (Rios, 1995, p. 24, grifos do autor)

Esse exercício da reflexão crítica que a ética, enquanto dimensão filosófica, deve averiguar na moralidade, talvez nos permita ultrapassar o emaranhado conceitual causado pelo moralismo que perpassa as discussões sobre o caráter obsceno das imagens na arte. Muitos historiadores, para abordar a arte como um valor entre valores, recorrem comumente ao sistema mais geral de valores de determinada época ou cultura e, assim, 
por exemplo, não deixam de assinalar a importância da retomada dos estudos clássicos para a arte da renascença, o cisma cristão para a arte barroca, os avanços da ciência para a arte impressionista, a influência de culturas ditas "primitivas" na arte modernista ou a estética do consumo, a liberação dos costumes e a indústria cultural para a arte contemporânea. Pois bem! Por que, então, paira sobre a pornografia, enquanto valor cultural que tem atravessado a arte há milênios (como valor presente na contemporaneidade ou de modo retrospectivo) uma introjeção eminentemente moralista e aquém do exercício crítico que a reflexão ética pode proporcionar? As respostas são múltiplas e uma citação de Meyer Schapiro pode nos indicar caminhos a serem explorados:

"O homem também se mostra na relação com aquilo que o rodeia, nos seus artefatos e no caráter expressivo de todos os signos e marcas que produz. Esses podem ser nobres ou ignóbeis, alegres ou trágicos, passionais ou serenos. Podem ainda suscitar estados de espírito inomináveis, e mesmo assim, portadores de uma enorme força." (Schapiro, 2001, p. 8)

De fato, as imagens do desejo e da sedução provocam sensações indescritíveis só murmuradas e gozadas entre quatro paredes - toda exposição com obras pornoeróticas deveria dispor de um dark room. E é justamente esse caráter provocador das imagens libidinosas que é escamoteado nos discursos sobre o corpo... A descrição que Mishima fez de seu primeiro gozo diante de uma imagem religiosa ainda soa como um sacrilégio.

Poul Gerhard, na introdução de seu Pornografia ou arte?, lembrando a etimologia do termo "pornografia", acrescenta:

"A partir deste ponto de vista básico, de modo diametralmente oposto ao do cristianismo, a palavra pornografia pode ser interpretada no seu contexto próprio. A arte pornográfica é, no sentido original do termo, 'inocente' e totalmente livre de dogmas religiosos ou morais. Pornografia significa aqui uma representação de um dos lados mais belos da vida humana, uma reflexão e uma ode ao gozo erótico." (Gerhard, 1971, p. 7)

Gerhard, percebendo que a relação entre arte e pornografia envolve questões morais e religiosas, propõe que a pornografia seja interpretada em seus próprios termos e contextos, tal como Jeudy e Vargas Llosa induziram nas citações anteriores. É nessa perspectiva que o pornoerotismo na arte deve ser abordado, isto é, como representação e reflexão sobre uma das mais belas experiências da vida humana, "uma ode ao deleite erótico" - e sem pudores, explícitos ou implícitos.

Enfim, no território múltiplo e complexo das visualidades eróticas e pornográ- 
ficas dos últimos quinhentos anos, a institucionalização da arte, considerada em seus limites canônicos, produz vários efeitos: 1) sublima o corpo; 2) edulcora a sexualidade e minimiza sua complexidade; 3 ) escamoteia a diversidade de expressões do desejo e 4) pasteuriza a sedução própria da imagem pornoerótica. Entretanto, muitos acham que esses efeitos são causados única e exclusivamente pela indústria pornográfica. Ao contrário, começo a perceber que é justamente a visualidade pornográfica que vem imprimindo algo de luminoso, de belo e brutal - maravilhosamente humano, enfim - ao sombrio mundo sub-erótico da história da arte. Nesse sentido, A origem do mundo de Coubert e as gravuras shunga japonesas representam o marco zero da liberação do corpo na arte. A partir daí, abre-se uma luxuriante vertente de exploração do corpo e de seus desejos no campo da arte em estreita relação com a cultura visual. Ato contínuo, poucos historiadores vão perceber esse conluio visual entre arte e cultura, entre paganismo e humanismo, mas suas vozes serão convenientemente esquecidas ou tornadas assépticas até o final do século 20 - Warburg é o exemplo por excelência.

A perspectiva da sobrevivência, da fantasmagoria e do anacronismo das imagens que Aby Warburg observou e Georges Didi-Huberman (2013) estendeu sobre os campos da arte e da cultura visual, nos autorizam a pensar a história da arte de modo não diacrônico e com uma pegada mais dialógica (antropológica e filosoficamente falando). A permeabilidade das fronteiras entre o erotismo e a pornografia se configura como uma dessas abordagens que permitem o reconhecimento de sobrevivências, fantasmagorias e anacronismos na história da arte e da imagem.

Antes de qualquer coisa, uma história da arte e da imagem que tenha como esqueleto o corpo e a sexualidade não pode ser etnocêntrica e monossexual como a maioria das histórias canônicas da arte - como, aliás, nenhuma história que se pretenda "geral" pode ser. As histórias da arte, salvo honrosas exceções, ainda estão impregnadas de um modelo que é claramente excludente e sua recepção acrítica tem causado a sobrevivência de visões hegemônicas, inclusive em muitas das compilações iconográficas publicadas nas últimas duas décadas sob o título de "arte erótica". Tratar do corpo e da sexualidade exige um alargamento do olhar e deve comportar revisões de paradigmas hegemônicos, inclusive os de gênero e, assim, deve-se enfrentar a sobrevivência da hierarquia iconográfica que privilegia o corpo feminino e a heteronormatividade.

Não será, necessariamente, uma história cronologicamente encadeada, um recorte exclusivamente diacrônico. Pouco importa que o percurso escolhido seja indutivo (das particularidades para o geral) ou dedutivo (do geral para as singularidades) ou a altercação de ambos; o que importa é a observação de três tipos de relações: 1) as sincrônicas, observáveis nas relações entre imagens num dado momento e/ou dado contexto; 2) as diacrônicas, perceptíveis nas relações temporalmente sucessivas entre imagens; e 3) as anacrônicas, que privilegiam as relações entre imagens distantes no tempo, no espaço e na cultura.

Dessa maneira, defendo a premissa de que ela não pode ser uma história de hierarquias, discriminando "artes maiores" de "artes menores", cultura popular de cultura erudita, cultura de massas de cultura de elite... Ao contrário, ela deve ser integrada e con- 
textualizada, relacionando fenômenos estéticos presentes tanto na arte quanto no campo mais vasto da cultura visual. Por esses motivos, a história pornoerótica da arte não pode ter por base única e exclusivamente a imagem musealizada, canônica, já carimbada com o valor de obra de arte. Visto que a complexidade da representação pornoerótica tem sido negligenciada pela maioria dos estudiosos da arte, há que se perscrutar a cultura visual e a história da imagem como um todo não só para encontrar nelas exemplos que se equivalem ou superam o canônico, mas, ao contrário, buscar na história da imagem valores que confrontam e desconstroem o próprio cânone, numa espécie de "filosofia da diferença" da qual nos fala Gilles Deleuze - é nesse sentido que utilizo aqui o termo "história da arte e da imagem". Nessa perspectiva, não poderá utilizar somente os enquadramentos que a história tradicional da arte utiliza, pelo menos nas histórias até a Pop Arte - no sentido que Hans Belting expôs em O fim da história da arte (1983/2006). Quase tudo o que é explicitamente sexual está excluído das histórias da arte e isso é mais um motivo para palmilhar a cultura visual em estreita relação com aquela, à maneira de Warburg. O campo mais amplo da cultura visual tem que ser considerado, pois é a partir deste arcabouço que a história da arte pode reelaborar seus modelos e paradigmas, estabelecendo interações e intercursos com o vasto mundo considerado "não-artístico", mas que lhe serve de eco e de retroalimentação.

Mesmo considerando que a imagem pornoerótica mantém algumas conexões com certos enquadramentos da história da arte - classicismo, simbolismo, expressionismo etc. - sua história não será abordada meramente como um gênero, movimento ou estilo da história da arte, dado que esses enquadramentos tornaram-se rarefeitos não só para a arte e para a visualidade contemporâneas, mas porque não dão conta das complexidades, mediações e diferenças que permeiam a representação da sensualidade. Num certo sentido será um atravessamento, tal como as histórias da fotografia, da pintura, da beleza, da feiúra etc. transcendem as fronteiras estabelecidas pela história da arte. Em outros termos, não deve ser um gueto mais ou menos tolerado pela história machista e eurocêntrica da arte, mas uma história disposta a perverter o próprio cânone.

A história pornoerótica da arte não será só uma história do gosto estético sobre o corpo e a sensualidade, mas também uma história dos arquétipos e estereótipos sexuais socialmente formatados. Nesse sentido, Filosofia, Antropologia, Sociologia, Psicologia e Literatura são disciplinas que oferecem importantes subsídios. Além disso, os estudos de gênero e a teoria queer - para ficarmos em dois exemplos - têm que ser resgatados de seus guetos e infectar as teorias consagradas sobre o tema. Além de Jeudy, Gehard, Vattimo, Batalle e Le Breton (citados neste ensaio) Foucault, Beauvoir, Welton e Butler são referências importantes. O recurso a esses autores não deixa de ser um procedimento temerário no campo profundamente endogenético da pesquisa em história da arte no Brasil. Entretanto, a tarefa mais importante é perscrutar atentamente as imagens pornoeróticas, de modo que elas mesmas revelem suas justificativas e modos de ser.

Os juízos de valor e de gosto - temor maior na anêmica crítica de arte na contemporaneidade - têm que ser percebidos, expostos, analisados e reavaliados. "Beleza", 
"feiúra”, "bizarro", “sujo", "limpo", “perversão", “nonsense” "sujeito", “objeto", “prazer” e "sofrimento" são alguns dos conceitos comumente utilizados em relação ao pornoerotismo e enquanto tais devem-se verificar seus modos de construção, desconstrução e reconstrução. Uma história pornoerótica da arte poderá subsidiar uma filosofia do corpo no caminho da sensualidade, da carnalidade, do prazer, do desejo e da sedução - filosofia esta a ser redimensionada, visto que a Filosofia, com poucas exceções, desconsiderou o corpo e seus apetites.

Presumivelmente, o pornoerotismo não ascende à condição de representação artística por ser considerado um tema "nada nobre", “óbvio", “não metafórico”... Então, a história da arte pornoerótica será a revelação da estética da obviedade; da carnalidade e não da espiritualidade; da diferença e não da identidade; do físico e não do metafísico; da imanência e não da transcendência; da finitude e não do eterno; do prosaico e não do romanesco... Será, provavelmente, uma história da poeticidade do intrinsecamente humano.

Pelo visto, a história e a revisão crítica da arte pornoerótica ainda estão por ser escritas e a tarefa é delicada e gigantesca, já que pressupõe um trabalho de arqueologia que livre a pornografia e o erotismo das muitas camadas de clichês sob as quais ficaram soterradas pelas histórias canônicas da arte.

Finalmente, nessa empreitada o pesquisador deve-se perceber como parte do processo que pesquisa, atento às próprias percepções e afecções que dirigem a construção ou a reconstrução de conceitos. Se sujeito e objeto encontrarem-se embaralhados e a excitação for soberana e inevitável, sigamos com o Adriano de Marguerite Yourcenar:

"Esta manhã, pela primeira vez, ocorreu-me a idéia de que meu corpo, este fiel companheiro, este amigo mais seguro e mais meu conhecido do que minha própria alma, não é senão um monstro sorrateiro que acabará por devorar seu próprio dono. [...] Numa coisa não te iludas porém; não estou ainda bastante enfraquecido para ceder às alucinações do medo, quase tão absurdas quanto as da esperança, e naturalmente muito mais incômodas." (Yourcenar, 1980, pp. 13-14) 


\section{Referências bibliográficas}

ARGAN, Giulio Carlo. Arte e crítica de arte. Lisboa: Editorial Estampa, 1993.

ARGAN, Giulio Carlo e FAGIOLO, Maurizio. Guia de história da arte. Lisboa: Editorial Estampa, 1994.

BAKHTIN, Mikhail. A cultura popular no Idade Média e no Renascimento - o contexto de François Rabelais. São Paulo; Brasília: Hucitec; Ed. UNB, 1993.

BAUDRILLARD, Jean. A transparência do mal - ensaio sobre os fenômenos extremos. Campinas: Papirus, 1992.

BELTING, HANS. O fim da história da arte. São Paulo: Cosac Naify, 2006.

CARDIM, Leandro Neves. Corpo. São Paulo: Globo, 2009.

DANTO, Arthur. Playng with the edge - the photographic achievement of Robert Mapplethorpe. In: HOLBORN, Mark e LEVAS, Dimitri (orgs.). Mapplethorpe. New York, 1992.

DELEUZE, Gilles e GUATTARI, Félix. O que é a filosofia? Rio de Janeiro: Ed. 34, 1997.

DIDI-HUBERMAN, Georges. A imagem sobrevivente - história da arte e tempo dos fantasmas segundo Aby Warburg. Rio de Janeiro: Contraponto, 2013.

DÖPP, Hans-Jürgen; THOMAS, Joe A. e CHARLES, Victoria. 1000 erotic works of genius. New York: Parkstone Press, 2008.

FABBRI, Paolo. Pensieri del corpo nudo. In: ZEVI, Claudia B. C. Il nudo fra ideale e realtá - dal neoclassicismo ad oggi. Firenze: ArtificioSkira, 2004.

GERHARD, Poul. Pornography or art? London: Words \& Pictures, 1971.

GREINER, Christine; AMORIM, Claudia. Leituras do sexo. São Paulo: Annablume, 2006.

LE BRETON, David. Adeus ao corpo - antropologia e sociedade. Campinas: Papirus, 2003.

MAHON, Alyce. Eroticism \& art. New York: Oxford University Press, 2005.

MATESCO, Viviane. Corpo, imagem e representação. Rio de Janeiro: Jorge Zahar, 2009.

MEDEIROS, Afonso. O imaginário do corpo entre o erótico e o obsceno - fronteiras líquidas da pornografia. Goiânia: Funape, 2008.

MISHIMA, Yukio. Confissões de uma máscara. São Paulo: Círculo do Livro, s/d.

RIOS, Terezinha Azerêdo. Ética e competência. São Paulo: Cortez, 1995. 
TOMKINS, Calvin. As vidas dos artistas. São Paulo: Bei, 2009.

VATTIMO, Gianni. Entrevista. In: Revista Cult no 126. São Paulo: Ed. Bregrantini, julho/2008, pp. 12 a 15.

VENTURI, Lionello. História da crítica de arte. Lisboa: Edições 70, 2007.

YOURCENAR, Marguerite. Memórias de Adriano. Rio de Janeiro: Nova Fronteira, 1980. 